\title{
Basal-Like Prostate Carcinoma
}

National Cancer Institute

\section{Source}

National Cancer Institute. Basal-Like Prostate Carcinoma. NCI Thesaurus. Code C138170.

Prostate carcinoma in which the CD49f signature is increased, the luminal markers and androgen receptor expression and signaling (androg en activity pathway) are not increased, and the proliferation score is higher than the luminal A prostate carcinoma. 